Stream: Inspiring Critical Thought

2017, Vol 9(1), 6-13

(C) The Author(s), 2017

http://journals.sfu.ca/stream

\title{
A Venezuelan Position on the Bolivarian Revolution
}

\author{
Douglas Amundaray \\ School of Communication \\ Simon Fraser University
}

My interest in politics started during my high school years. At 13 I got hooked on the Venezuelan political scenario with the same intensity as most adults. It is not usual for a teenager to be interested in politics, but the impact of the 1998 Venezuelan presidential election was so significant, the coverage by media so widespread, that it was practically inevitable that I would become enthralled in the outcome. "How does who you are and where you stand in relation to others shape what you know about the world?" By raising this question, David Takacs (2002) introduces the importance of positionality to knowledge production. Positionality provides a way to understand how objective or subjective researchers are during knowledge production (Lave \& Wenger, 1991). I can firmly say that the representations portrayed in Venezuela's mainstream media built up my character, and shaped the analytical approach that I follow today as a scholar.

I believe that reflecting on our positionality is a process that requires deep introspection. Positionality has been conceptualized as a core factor in data collection (Ganga \& Scott, 2006). And by being consciously reflective during the research process, not only do we become aware of new considerations for analysis, but we also open up possibilities of knowing our positionality better. This process of reflection also involves critical engagement that is directly connected to our experiences. Etherington (2004) argues that critical engagement:

allows us to check for distortions in our interpretations that might be based on past experiences held outside our full awareness, or based on indoctrination within our personal or social cultures that we may have accepted without question since early childhood (p.29).

These perceptual frameworks determine and contribute to our understanding of issues that could arise during research. Indeed, we must recognize the internal and external aspects that drive us towards the questions we ask, the analysis we produce, and the representations we make.

When I decided to pursue my Master degree, I knew that I wanted to produce meaningful work about the political situation and the transformation of media spheres in my country. I argue that Venezuela's political structure has set a precedent in the region in the last years, and it is an example of how unlimited power may disrupt the most honest pursuits and the fortune of an entire nation. In this essay, I discuss my positionality as a male communicator who grew up and was educated during the major political shift that Venezuela has experienced over the past 18 years. I 
reflect on how those experiences shaped my academic and professional endeavours. In particular, I discuss the challenge of balancing objectivity and positionality when studying a country and a context that I feel passionate about. I also suggest that it takes first-hand experience to really understand what life is like in Venezuela today, which makes me question the arguments of outsiders who celebrate the revolution without having to live in it.

\section{Growing up in Revolutionary Times}

The Bolivarian Revolution started when Hugo Chávez took office in 1999. It represented a complete transformation of the Venezuelan political system, and it was received with enthusiasm and also doubt. For the first time in forty years, an exhausted electorate saw in Chávez an option that promised to empower citizens by detaching the country from the predominance of neoliberal structures that had influenced the country for decades.

During the neoliberal period, the main political parties, Acción Democrática (AD - Democratic Action) and Comité de Organización Política Electoral Independiente (COPEI - Independent Political Electoral Organization Committee), held on to power without any strong opposition. These parties were highly institutionalized, and they had developed alliances that satisfied the particular goals of their leaders and members. Although there was a commitment to representative democracy, their bipartisan control allowed AD and COPEI to command institutions such as the Supreme Court and the Congress, regardless of the party that was occupying the presidency (Ellner \& Hellinger, 2003). There was no real political competition and society had become numb to this dynamic. The alliance between these parties was carefully crafted to avoid rivalry or civic mobilizations that might disrupt the political order (Linz \& Stepan, 1996). During this period, Venezuelans did not talk about their situation in terms of anti-imperialism. Bilateral relations with capitalist countries such as the United States were somewhat effective for both countries, and the Venezuelan leadership did not have a strong nationalist discourse.

But behind the scenes, an unknown military officer named Hugo Rafael Chávez Frías decided to pursue a political change by organizing movements among military corps who were discontent with the old neoliberal model established by $\mathrm{AD}$ and COPEI. This is how the Revolutionary Bolivarian Movement 200 was formed. Under Chávez's direction, this group organized two coups d'état in 1992 that aimed to remove President Carlos Andrés Pérez from his residence at Palacio de Miraflores. These attempts put Chávez in jail and failed to ignite immediate change, but he was resolute in his intentions. His efforts had made him a hero among marginalized groups and those who did not embrace the agenda of $\mathrm{AD}$ and COPEI. This is because:

The political ascendency of Chávez is deeply intertwined with the struggle over neoliberalism. The self-destruction of Venezuela's so-called 'stable democracy' occurred through the 1990s as social polarization and turmoil emerged in response to the International Monetary Fund 
(IMF) and the United States backed efforts to impose neoliberal austerity, including major rioting in Caracas over the implementation of structural adjustment policies.

(Albo, 2006, p.1)

This may be true, but it is also true that Chávez's actions laid bare the shortcomings of the neoliberal system which had become unsustainable in Venezuela. Structural adjustments harmed the bi-partisan oligopoly of AD and COPEI. After 1992, the deterioration of the old order had officially begun and it was unstoppable.

So, although Chávez ended up in jail, his acts sparked social turmoil which destabilized the political order. Radical 'Chavistas' started to organize groups to support him. This created a mass of political capital which paid off when Chávez was released from jail. He traveled around the country promoting his populist agenda, and building up credibility with the electorate. Learning from his mistakes, Chávez surrounded himself by experienced leftist politicians and peers from the military forces who were patriotic defenders of the nation. They helped him structure his ambitions and crafted strategies that eventually blew up the traditional political apparatus, this time not from the shadows of insurrection. Chávez's political party Movimiento Quinta República (MVR - the Fifth Republic Movement) was the first civic-military alliance in Venezuelan history, and it formed the platform that allowed him to win the presidential election in 1998 (Albo, 2006). Chávez defeated media projections, detractors, traditional parties and experienced candidates to become the new President of Venezuela.

From early on, political polarization between opposition parties and Chávez supporters was acute. Before Chávez's administration, the political system of Venezuelan had well-structured political institutions (Villa, 2005), however they were quite rigid and controlled by elites, so they did little to acknowledge the voices, interests or needs of people without power, poor communities or independent movements. That changed once Chávez took office with the creation of the Partido Socialista Unido de Venezuela (PSUV - United Venezuelan Socialist Party) and the implementation of policies that promoted institutional changes. These changes were advanced through Chávez strong ties to the military, and mobilization of popular sectors. The impact of these reforms was so strong that within the next years the influence of AD and COPEI was greatly diminished. Although new socalled 'democratic' parties arose, none of them could compete with the PSUV.

Chávez also began to reorganize the country around his ideals. A new Constitution was approved in a popular referendum on December 15, 1999. It changed the name of the country to the Bolivarian Republic of Venezuela, wiped out the Congress, and extended the presidential term from five to six years with the possibility of reelection, which meant that Chávez's presidency was likely to last for 13 years. The reason for extending the term and allowing immediate reelection was that 'rebuilding' Venezuela would take more than five years. However, during most of his presidency, Chávez indicated that rebuilding the country could last until 2021 (Wilpert, 2003). Later in 2009, using his power as a President, and with most legislative and electoral institutions under his control, Chávez introduced a project to hold a referendum on whether the Constitution should be amended 
to eliminate term limits for president, governors, mayors and deputies for the National Assembly. On February 15, 2009, the referendum was approved by $54 \%$ of the electorate.

The role of the military was also strengthened in the new Constitution, which should not be surprising considering Chávez' military background. Military officers were given the right to vote, and military promotions were approved directly by Chávez. This was the opportunity for Chávez to control the military force and place active military officers in different public institutions. Some of those officers were part of the coup attempts that Chávez plotted in 1992, such as Jesse Chacón, Diosdado Cabello and Francisco Árias Cardenas. During Chávez's presidency, they were designated Ministers, Governors, and Vice-presidents, and changed roles according to Chávez's needs. The civil rights given to the military blurred the line that divided the average citizen from the armed forces. The combination of a Chavista military fiercely loyal to the Bolivarian Revolution, armed militias with no military training and a fiery rhetoric promoted by the socialist leadership have been particularly dangerous for the country. These groups have joined forces to defend the Bolivarian Revolution against any detractors.

Although these new changes were seen as drastic by some sectors of society, the inclusion of popular referendums in the Bolivarian Constitution promoted the ideal of participatory democracy. Four types of referendums were outlined: consultative, rescinding, approving and recall, which can be activated by collecting signatures from at least 20 percent of the electorate. This '21st Century' participatory model was a cutting-edge innovation that set Venezuela's politics apart from the neoliberal models of most Western democracies.

As a result of this social, political and economic upheaval, the way Venezuelans consume information has changed radically in the past 18 years. Before Chávez, private media enterprises ruled Venezuela's media landscape vis-á-vis publicly regulated media concessions. Private media in Venezuela was commanded by wealthy corporations and businessmen, who were part of an authoritarian neoliberal society (Park \& Curran, 2000). Free market policies capitalized on "celebrity banal culture, game show aesthetics, and a politics of precarity, control, and mass surveillance" (Giroux, 2015, para. 2). Chávez's new participatory democracy required a new informational infrastructure to link the government to the people.

Chávez's 2005 Ley de Responsabilidad Social en Rádio y Televisión (Ley RESORTE - Law for Social Responsibility in Radio and Television) imposed restrictions on private media corporations, and promoted public service broadcasting that would support the democratization of the state media system. Restrictions on private media increased and reached their maximum in May 2007 when the transmission rights of Radio Caracas Televisión (RCTV) were revoked. Before Chávez, public media had just one channel: Venezolana de Televisión (VTV) which struggled to bypass the hegemony of the private media. From 2002 to 2009, the state funded and financed four more public stations: Televisora Venezolana Social (TVES) which replaced RCTV, Visión Venezuela (ViVe), Asamblea Nacional Televisión (ANTV) and Ávila TV. The government started to shape the future of public television channels by delegating control to working-class communities, trade unions and independent producers, which has paved the way for "non-commercial, non-capitalist media 
production" (Artz, 2009). By 2015, there were 516 private, 98 public and 262 community access FM stations. For AM stations, 171 were private and 21 public. On the other hand, the number of television broadcasters increased to 198 private, 96 public and 44 community television stations (Conatel.gob.ve, 2015).

Besides the transformation of public and private media, the Venezuelan government has actively supported alternative media by reassigning transmission concessions to sectors that promote grassroots communication. Here the intent was to give voice to segments of society that formerly had no way of representing themselves in the public sphere. Meanwhile, the internet and new communication channels such as Twitter, Facebook, Youtube, blogs, and websites had provided a platform for those sectors of society that had a voice before but lost it due to political intervention. Although online journalism has provided an escape from Venezuela's media chaos, the internet has not escaped Chávez's influence. In 2009, Chávez signed Decree-law No. 6,649 which establishes internet purchases as "superfluous or luxury spending" and not a priority for the nation. Additionally, President Nicolás Maduro cut the budget allocated to sumptuous expenses by 20 percent in 2014, pulling back projects to improve the infrastructure of the telecom sector. According to the Economic Commission for Latin America and the Caribbean (ECLAC), Venezuela has the slowest broadband speed of the region (1.9 Mbps in 2016).

In sum, the Chavista government carried out a full overhaul of the Venezuelan media system, emphasizing public and community media and taking power away from private media. While these reforms were portrayed as necessary for popular participation in the management of the Venezuelan state, the truth is that Chávez capitalized on them to establish a communicational hegemony. Although Chávez's detractors (many of whom were harmed by these changes) rejected this dramatic shift, the truth is that the new Bolivarian communicational hegemony replaced the old communicational hegemony of private media.

At a very young age, I had the chance to experience all of these changes and the shifting balance of power between Chávez and his opposition. Much of what has happened in Venezuela is idealized or vilified by external commentators in the news or in academic circles. But these commentators have the luxury of offering general impressions or using Venezuela as a case study to support their ideological agendas, without having to live out the reality of what is happening in the country. The Venezuelan revolution changed the dynamic of an entire society, separating friends, and dividing families. Personally, the hardest part of it are the enmities that have emerged with friends and family. I have relatives and acquaintances that support the Bolivarian Revolution. Now, some of them living elsewhere in the world, enjoy the benefits of capitalism and spend their dubiously acquired wealth. These experiences and relationships have shaped my research questions, and they

have also shaped the person who I am today. They make me want to challenge power in Venezuela from my own personal standpoint.

\section{First Hand Experiences of Media Reform in Venezuela}


As an undergraduate student, I developed a full-fledged interest in the Venezuelan political context with a particular focus on the interplay between media and politics. Although I knew that my future career would be directly affected by the changes taking place in the country, I was determined to thrive and pursue my personal goals. This turned out to be harder than anticipated.

During my undergraduate degree, I landed my first job as a journalist for a popular tabloid in Caracas. It was exciting to be "on call" to chase down the news. Even though I enjoyed this experience, I was appalled to discover that unconfirmed information was often used to create headlines. I continually asked myself how, in a country where political polarization determines pretty much everything, this type of irresponsible practice could be allowed to continue. Over time I have come to understand that this type of journalism has promoted a culture of urgency, which is symptomatic to the heated economic and sociopolitical condition of Venezuela, and intends to fill the gaping holes torn open by an ideological divide. Also, these practices were a reaction to rampant repression and censorship that reached its maximum when RCTV was forced to close.

Through my work, I was directly connected to colleagues from different media outlets, including colleagues who worked at RCTV, when the transmission rights were revoked. As a journalist, as a student and as a Venezuelan who did not-and does not-support the government, I lived this episode with intensity. I attended all the protests, was threatened by the police and watched my colleagues lose their jobs. Following this, my role as a journalist lost direction. Fear of political retaliation dramatically reduced my options and opportunities. At that moment, I decided to change my path to corporate communications. Although I was ready to embrace new challenges, I always tried to stay connected with politics. However, politics in Venezuela's Bolivarian Revolution is always a constant fight against the system. Very few are capable of working in this compulsive environment, much less thrive. Defending what you stand for in Venezuela requires more than passion; you need courage and willingness to tackle the shortcomings, risking all what you have. When your integrity and safety are challenged, it may be necessary to evaluate your priorities.

These experiences were paramount to my growth as a professional and scholar, and have helped to define my research interests. I have had a chance to experience how media functions in Venezuela, and I have seen the role of politics in shaping the media. My challenge now is to think about how I will recount the story of media and politics in Venezuela. How does who I am and where I stand in relation to others shape what I know about the world? How will it shape the story I tell about those experiences?

\section{A Primary Position on the Revolution}

A careful reader will discern my positionality as a Venezuelan citizen with a strong political stance against the current administration. However, I hope to prevent my personal biases from colouring my research excessively. It is important for me to establish trust with my peers, and to do so on the basis of quality research about the Venezuelan media. During my literature review, I found that much of what is written about the Venezuelan media, is written by outsiders who are distant from 
the 'on the ground' reality. Some accounts are quite biased, such as the one provided by communications scholar Lee Artz, which is heavily shaped by his leftist positionality.

From my perspective, despite the growth in media outlets in Venezuela over the past years, and their representation of public, private, citizen and alternative sectors, the country suffers from a profound lack of pluralism. I would like to analyze what has happened in Venezuela, rather than just criticize. I aim to explain this situation from my perspective as an insider-as a person who lived these changes and can leverage his identity to explain them further. I believe that making a distinction between the field (media) and my home (Venezuela) could help me to explore my findings as both insider and an outsider, striking a balance between objective and subjective research (Gilbert, 1994; Mullings, 1999).

I aim to address issues such as the role data and statistics play in the media as political tool to influence marginalized sectors of society. Additionally, I would like to study the interplay between traditional and online journalism, and how the latter has been used as an alternative outlet to voice the opinion of those sectors that have lost spaces of participation in the reformed media landscape. Understanding these dynamics raises questions regarding freedom of speech, equality and pluralism not just in Venezuela, but in the entire Latin America region, which has been influenced by the changes happening in Venezuela.

As a graduate student, I always aim to engage in meaningful work, and this already is a significant responsibility. But my positionality makes my work that much more meaningful. I am the only Venezuelan in my class, and this gives me a degree of authority and responsibility for the work I produce. For that reason, this project is important to me, and I hope that it will provide a new perspective on the Venezuelan media that has not been addressed before.

Sharing my work with authentic audiences motivates me to produce an analysis that can be impactful. Although my experiences are valuable, I do not want them to over-determine my research. By understanding the role of media in Venezuela and outlining possible solutions, I shall address Venezuelan's desire for justice. I hope my research can assist Venezuela in achieving human rights, cooperation, compassion, communality and nonviolence (Hamelink, 2011).

Regardless of our research interests, our positionality merges objectivism and subjectivism, and they must be brought together to complement each other. My research must reflect the facts, but it must also offer an analysis, and if possible, these two things can come together to provide a solution for the media situation in Venezuela. I cannot claim to speak for all Venezuelans, but perhaps my ideas can start a conversation, and in this way we can begin to move towards new changes that will

resolve the current difficulties faced by the country. I'm hopeful that the media can be part of these changes and play a role in a transition to a new democracy.

\section{References}

Albo, G (2006). The unexpected revolution: Venezuela confronts neoliberalism. Retrieved from https://www.socialistproject.ca 
Artz, L. (2012, May 1). Venezuela: making a 'state for revolution' - the example of community and public media. Retrieved from http://links.org.au/

Conatel.gob.ve (2015). Cifras del Sector Comunicaciones [online]. Retrieved from http://www.conatel.gob.ve

Park, M., \& Curran, J. (2000). Authoritarian neo-liberal societies. In M. Park \& J. Curran (Eds.), DeWesternizing media studies (pp. 84-124). London, UK: Routledge.

Ellner, S., \& Hellinger, D. (2003). La politica venezolana en la época de Chávez: clases, polarización y conflicto. Caracas: Nueva Sociedad.

Etherington, K. (2004). Becoming a reflexive researcher: Using ourselves in research. London, UK: Jessica Kingsley.

Gilbert, M. R. (1994), The politics of location: Doing feminist research at "home". The Professional Geographer, 46, 90-96. doi:10.1111/j.0033-0124.1994.00090.x

Giroux, H. A. (2015, November 4). Beyond dystopian visions in the age of neoliberal authoritarianism. Retrieved from http://www.truth-out.org

Hamelink, C. J. (2011). Media and conflict: Escalating evil. Boulder, CO: Paradigm Publishers.

Lave, J. \& Wenger, E. (1991). Situated learning: Legitimate peripheral participation. Cambridge, UK: Cambridge University Press

Linz, J., \& Stepan, A. (1996). Problems of democratic transition and consolidation: Southern Europe, South America, and post-communist Europe, Baltimore, MD: Johns Hopkins Univ. Press.

Mullings B. (1999). Insider or outsider, both or neither: Some dilemmas of interviewing in a crosscultural setting. Geoforum, 30, 337-350.

Repositorio.cepal.org. (2016). Estado de la banda ancha en América Latina y el Caribe 2016 [online]. Retrieved from: http://repositorio.cepal.org

Ganga, D., \& Scott, S. (2006). Cultural "insiders" and the issue of positionality in qualitative migration research: Moving "across" and moving "along" researcher-participant divides. Forum: Qualitative Social Research, 7(3), article 7.

Takacs, D. (2002). Positionality, epistemology, and social justice in the classroom. Social Justice, $29(4), 168-81$.

Villa, R. D. (2005). Venezuela: political changes in the Chávez era. Estudos Avançados, 19(55), 153172. doi: 10.1590/S0103-40142005000300011

Wilpert, G. (2003, November 14). Community Airwaves in Venezuela [online]. NACLA. Retrieved from https://nacla.org/ 